\title{
Assessment of the level of chromium species in the discharged effluents of Haik and Debre Berhan tanneries in the Amhara Region using ICP-OES and UV-VIS spectrometry
}

\author{
Teame Hadgu ${ }^{1}$ and Meareg Amare ${ }^{2 *}$ \\ ${ }^{1}$ Adwa College of Teacher Education, P. O. Box 91, Adwa, Tigray, Ethiopia \\ ${ }^{2}$ Department of Chemistry, Bahr Dar University, P. O. Box 79, Bahr Dar, Ethiopia
}

\begin{abstract}
The purpose of this study was to assess the level of chromium species in the discharged effluents of selected tanneries in the Amhara Region; Haik and Debre Berhan tanneries. The level of total chromium, and hexavalent chromium in the discharged effluent of the studied tanneries were determined using the ICP-OES, and UVVis spectrometry, respectively. The level of trivalent chromium species in the samples was then estimated by difference. Recovery results in the range 96.3 to $103.3 \%$ verified the applicability of the methods for the determination of the chromium species in the effluent samples. One way ANOVA statistical analysis was used to check whether the results between sampling months were statistically different or not. The mean concentration of Chromium (VI) before and after treatment in the effluent of Haik tannery was $0.618 \pm 0.076$ and $0.123 \pm 0.064 \mathrm{ppm}$ while in the effluent of Debre Berhan tannery, $0.070 \pm 0.009$ and $0.039 \pm 0.005 \mathrm{ppm}$, respectively. Similarly, the average total chromium concentration before and after treatment in the discharged effluents of Haik and Debre Berhan tannery was $4,772.3 \pm 2.4$ and $392.7 \pm 1.7 \mathrm{ppm}$, and $512.8 \pm 1.1$ and $325.0 \pm 0.3 \mathrm{ppm}$, respectively. Although the average levels of chromium species over the sampling times looked not much higher than the permitted levels, some of the results indicated that the factories release effluent which is extremely loaded with chromium species including the most toxic form of chromium (hexavalent chromium). The assessment results in general showed the pollution of the river waters into which the studied tanneries are discharging their effluent.
\end{abstract}

Key Words/Phrases: Debre Berhan tannery, Inductively coupled plasma-optical emission spectrometry, Diphenylcarbazide, Recovery study, Tannery effluent, UV-Visible spectrophotometry

DOI: http://dx.doi.org/10.4314/ejst.v9i2.5

\section{INTRODUCTION}

Water is an essential component for survival of life on earth, which contains minerals, important for humans as well as for earth and aquatic life (Arian and Kazi, 2008). Water pollution is a serious environmental problem in the world. It is the degradation of the quality of water that renders water unsuitable for its intended purpose. Anything which degrades the quality of water is pollutant (Dixit and Tiwari, 2008; Zenabu Yirgu, 2011).
Water pollutants can be broadly classified as organic, inorganic, suspended solids and sediments, heavy metals, radioactive materials and heat (Zenabu Yirgu, 2011). Among different pollutants, heavy metal pollution of the aquatic environment has become a great concern in recent years because they are very harmful as a result of their nonbiodegradable nature, long biological half-life and their potential to accumulate in aquatic ecosystems (Arian and Kazi, 2008; Moore et al., 2009; Benzer et al., 2013).

\footnotetext{
*Corresponding author: amaremeareg@yahoo.com

(C) This is an Open Access article distributed under the terms of the Creative Commons Attribution License (http://creativecommons.org/licenses/CC BY4.0).
} 
Effective water management and control of pollution are very important for maintaining ecological balance and human well-being. Inorganic pollutants especially mercury, cadmium, lead, copper, chromium and nickel discharged from industries get into human food chain, enter the human body and disturb biochemical processes leading to diseases such as skin allergies, dermatitis and ulcerations, cirrhosis of liver, skin cancer, etc (Satyajit and Sukalyan, 2012).

Chromium is used in several industries such as metallurgical (steel, ferrous- and nonferrous alloys), refractory (chrome and chrome-magnesite) and chemical industries (pigments, dyes, electroplating, tanning, cooling water, leather and wood preservation and cement manufacturing). As a consequence of these industrial activities, chromium compounds enter the environment causing pollution (Han et al., 2007; Hagendorfer et al., 2008).

Chromium is a naturally occurring element present in water, sediments, rocks, soils, plants, biota, animals, and volcanic emissions under various chemical, physical, and morphological forms (Siraj et al., 2012). The two main oxidation states of chromium, $\mathrm{Cr}(\mathrm{III})$ and $\mathrm{Cr}(\mathrm{VI})$, present in natural waters, significantly differ in biological, geochemical and toxicological properties. Over a narrow concentration range, trivalent chromium is considered essential for mammals for the maintenance of glucose, lipid and protein metabolism, whereas $\mathrm{Cr}(\mathrm{VI})$ is reported to have a toxic effect on humans (Lin et al., 2001; Monteiro et al., 2002).

In a solution state, $\mathrm{Cr}(\mathrm{VI})$ may exist in three different ionic forms, such as hydro chromate $\left(\mathrm{HCrO}_{4}^{-}\right)$, chromate $\left(\mathrm{CrO}_{4}^{2-}\right)$ and dichromate
$\left(\mathrm{Cr}_{2} \mathrm{O}_{7}{ }^{2-}\right) . \mathrm{Cr}(\mathrm{VI})$ in the form of water-soluble complex anions in a surface-water which is rich in organic matter undergoes reduction to $\mathrm{Cr}$ (III) possessing a much shorter lifetime (Callahan et al., 1979). The proportion of each ion of $\mathrm{Cr}(\mathrm{VI})$ in solution is $\mathrm{pH}$ dependent that in basic and neutral $\mathrm{pHs}$, the chromate form predominates whilst at lower $\mathrm{pH}$ (6.0 to 6.2), the hydro chromate concentration pre-dominates (EPA, 1984; Dhungana and Yadav, 2009).

The high toxicity of $\mathrm{Cr}(\mathrm{VI})$ is related to its ability to cross the cell membrane and its strong oxidation properties (Girard et al., 1996). Hexavalent chromium is readily soluble in water and can be accumulated in soil and plants (Kumar et al., 1997), while Cr(III) probably exists in environmental waters in the form of many different species: hydrolysed, complexed, and adsorbed on colloidal matter. Also, $\mathrm{Cr}$ (III) can undergo speciation changes from inorganic form to organic complex by plants, being transported as carboxylate complex (Juneva and Prakkash, 2008). Although most of the chromium discharged from industries including tanneries is the trivalent chromium (Pankow et al., 1974), in the natural environmental compartments like soil and water, the interconversion of Chromium species takes place readily, depending on $\mathrm{pH}$, redox potential, and ligands available (Kumar et al., 1997) yielding the toxic chromium species $(\mathrm{Cr}(\mathrm{VI}))$.

The toxicological impact of chromium (VI) originates from the action of itself as an oxidizing agent, formation of free radicals during the reduction of $\mathrm{Cr}$ (VI) to $\mathrm{Cr}$ (III) occurring inside the cell, and its ability to pass through cellular membranes many orders of magnitude faster than does the chromium (III) species (Ricardo et al., 2009). 
Hides and skins have the ability to absorb tanning acid and other chemical substances that prevent them from decaying, make them resistant to wetting, and keep them supple and durable (AbdelShafy et al., 1995). Tanning is essentially the reaction of collagen fibers in the hide with tannins, chromium, alum, or other chemical agents. The common tanning agents used in most leather industries is trivalent chromium in the form of basic chromium sulfate or vegetable tannins extracted from specific tree barks (Abdel-Shafy et al., 1995).

Chrome-tanned leather tends to be softer and more flexible than vegetable-tanned leather, has higher thermal stability, is very stable in water, and takes less time to produce than vegetable-tanned leather making chrome tanning of choice (Ackay et al., 2003).

The amount of chromium salt added for tanning being about $8 \%$ of the leather weight, $30 \%-40 \%$ of the total chrome added is not fixed to the leather and hence is discharged in the tannery effluent causing environmental pollution (Abass et al., 2005). Besides, tannery wastewater is usually homogenized with the rest of industrial effluents causing the chrome component to precipitate as chromium hydroxide, thus retained in the sludge of the water treatment plants. Another environmental impact, which cannot be easily corrected in tannery wastewater, is salinity (Kotai and Stasicka, 2000). The dynamic inter conversion between $\mathrm{Cr}$ (III) and $\mathrm{Cr}(\mathrm{VI})$ in aqueous environments may lead to a health risk. Presently, Ethiopia's leather industry is in the leading position of the leather sector development within the Eastern and Southern Africa region (UNCTAD, 2002). The number of Industries in general and Tanneries in particular is growing drastically. Hence, assessing the level of the potential environmental pollutants like the chromium species in tannery effluents is necessary before causing an irreversible pollution effect on the environment.

Spectroscopic techniques are among the most reported techniques for the speciation and determination of chromium in real samples like tannery discharges (Balogh et al., 2000; Li et al., 2001; Revanasiddappa and Kiran Kumar, 2002; Revanasiddappa and Kiran Kumar, 2003; Telepeakova et al., 2005; Zaitoun, 2005; Addis Mekonnen, 2006; Dayananda and Revanasiddappa, 2007; Fabiyi and Donnio, 2007; Abraha Gebrekidan et al., 2009; Pranvera, 2009).

To the best of our knowledge, no assessment has been conducted on the level of chromium species in the discharged effluents of Haik, and Debre Berhan tanneries in the Amhara Region. In the present study, two spectroscopic techniques; the ICP-OES for the determination of total chromium and UV-Visible based on 1,5-diphenylcarbazide (DPC) method as a complexing agent for the determination of hexavalent chromium in the discharged tannery effluent of Haik and Debre Berhan tanneries (both with waste treatment plant) were employed. The trivalent chromium concentration was estimated by difference method between the ICP-OES and UV-Visible spectrometric results.

\section{EXPERIMENTAL}

\section{Description of the study area}

This study was conducted at Haik and Debre Berhan tanneries in the Amhara Region, Ethiopia, both having treatment plant. Haik tannery is located in Haik town, South Wollo. Samples were collected from two sites; before treatment located 


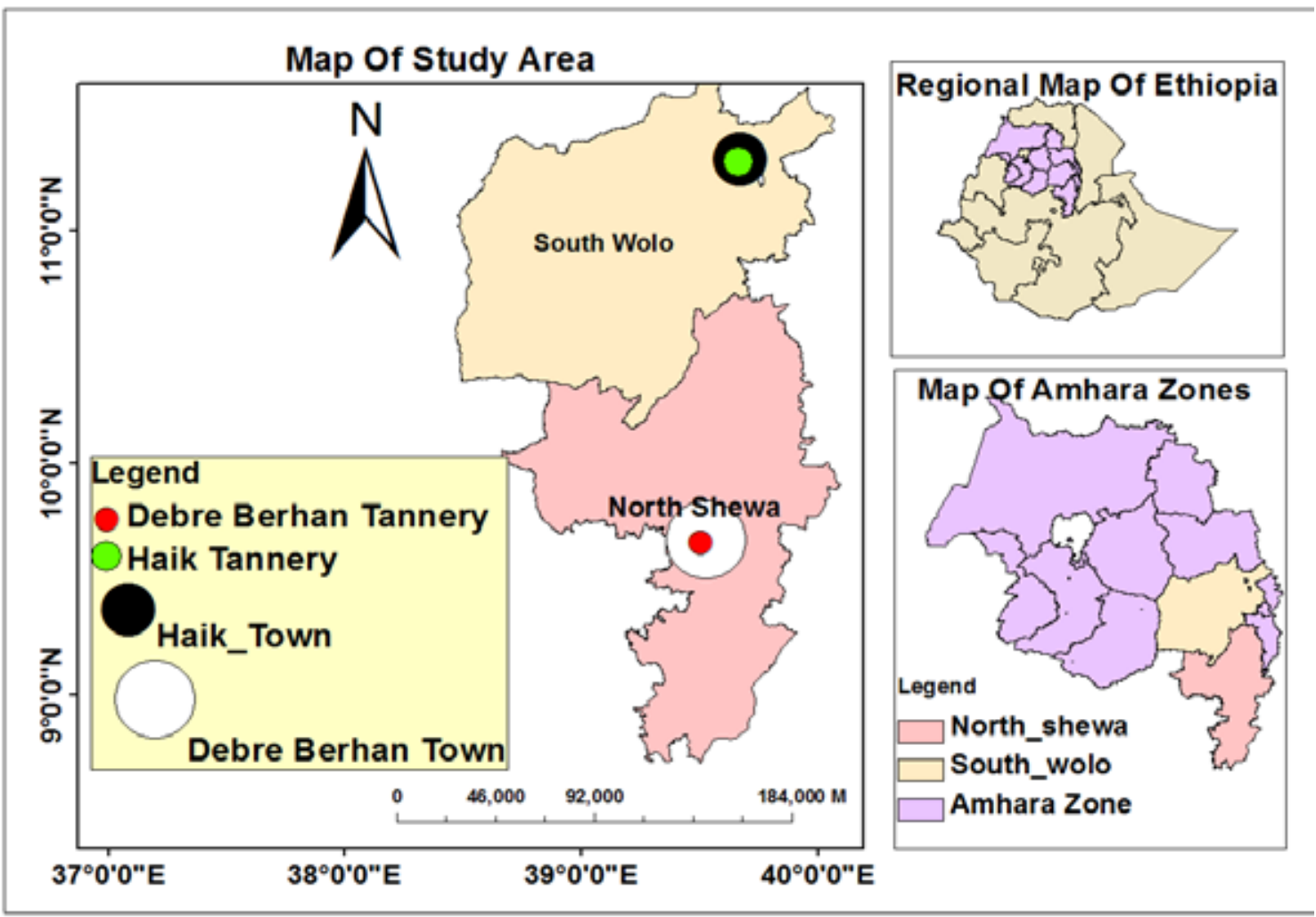

Figure 1. Map of the study area; SOURCE: survey data of GPS and ARCGIS 10 share file.

$11^{\circ} 19^{\prime} 19.35^{\prime \prime}$ North latitude and 39 40'30.91" East longitude and after treatment located $11^{\circ} 22^{\prime} 49.25^{\prime \prime}$ North latitude and $39^{\circ} 40^{\prime} 22.81^{\prime \prime}$ East longitude. The treated tannery effluent is discharged directly to 'Ketie' (or Gelana) river.

Debre Berhan tannery is located in Debre Berhan town, North Shewa. Samples were collected from the factory at just before and after the treatment plant located $9^{\circ}$ 42'38.17" North latitude and $39^{\circ} 28^{\prime} 30.85^{\prime \prime}$ East longitude and 9 $42^{\prime} 30.02^{\prime \prime}$ North latitude and $39^{\circ} 28^{\prime} 18.97^{\prime \prime}$ East longitude, respectively. The treated effluent in this case also is discharged to Beriesa river, which is used by the people around for different domestic activities.

The study areas were mapped by Geographical Information System (GIS) using information obtained by Global Positioning System (GPS) and the study map is presented in Figure 1.

\section{Sampling and sample collection}

In this study, random sampling technique was used to collect effluent samples for three times (February 12 - 13, May 07 - 08, and May 27 - 29, 2015) from the two tanneries. $1000 \mathrm{~mL}$ Polyethylene plastic bottles were prepared for sample collection first by washing with concentrated nitric acid and then rinsed with distilled water to avoid contamination. In both tanneries, samples were taken from the effluent stream just before entering the treatment plant and immediately after treatment plant. Tannery effluent samples from each sampling site were collected by direct immersion of bottles on effluent sample site. The photographs of the sampling sites of both tanneries are presented in Figure 2.

\section{Sample pre-treatment}

All the tannery effluents collected from Haik and Debre Berhan tanneries before and after treatment were acidified by adding $10 \mathrm{~mL}$ of 

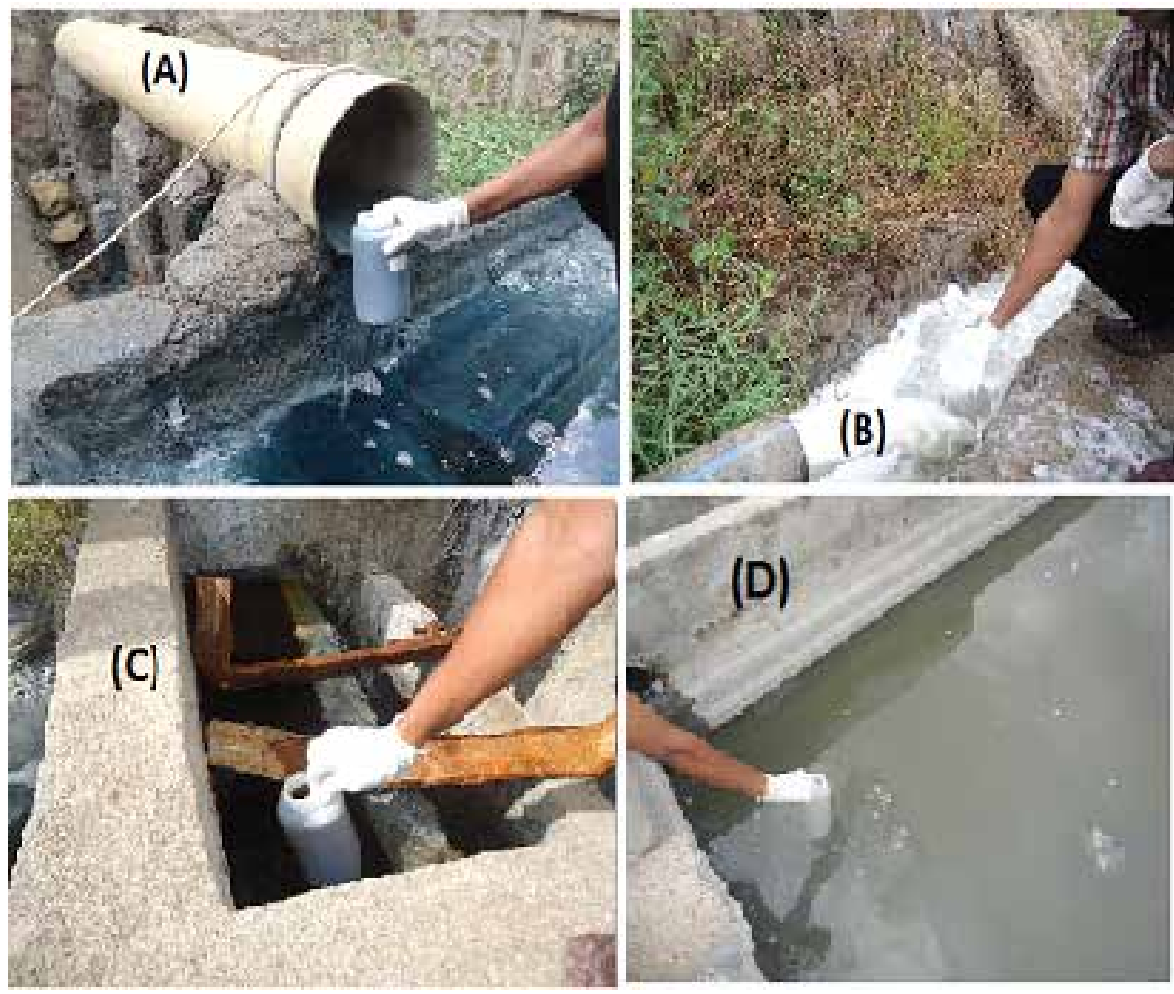

Figure 2. Sampling sights: (A) Haik tannery before treatment, (B) Haik tannery after treatment, (C) Debre Berhan tannery before treatment, and (D) Debre Berhan after treatment.

concentrated $\mathrm{HNO}_{3}$ to each $1000 \mathrm{~mL}$ as soon as collected from the sampling sites. For UV-Visible spectrophotometer analysis, each acidified tannery effluent was also filtered with a quantitative filter paper in to a volume of $25 \mathrm{~mL}$ and preserved until the next real tannery effluent preparation step for analysis.

For ICP-OES analysis, acidified effluent samples were digested to destroy organic matter and other interfering matrices.

\section{Instruments and apparatus}

UV-Visible double beam spectrophotometer (LAMBDA 35, PerkinElmer); Inductively coupled plasma optical emission spectrometer (ULTIMA 2, HORIBA scientific); a refrigerator (FR 1082); a digital electrical balance (PW 124) with a precision of \pm 0.0001; and a pH-meter (AD8000, Romania Europe) were used.

\section{Chemicals}

1,5-diphenylcarbazide (98\%, Hightech health care), Nitric acid (70\%, Lobal chmie laboratory reagents and fine chemicals), Perchloric acid (70\%, BLULUX laboratories), Ortho phosphoric acid (85.74\%, Fisher scientific), potassium di-hydrogen phosphate (Titan Biotech Ltd), and potassium dichromate (BLULUX laboratories) all of which of analytical grade were used without prior purification. Distilled deionized water (DDW) was used for solution preparation throughout the work.

\section{Solution preparation}

\section{Preparation of phosphate buffer solution}

Phosphate buffer solution (PBS) of $\mathrm{pH} 2$ was prepared by mixing the appropriate volumes of equimolar $(0.1 \mathrm{M})$ phosphoric acid and potassium di-hydrogen phosphate solution. The $\mathrm{pH}$ of the mixture was adjusted using concentrated phosphoric acid and potassium di-hydrogen phosphate solutions. 


\section{Preparation of standard chromium solutions}

Standard chromium (VI) stock solution of 1,000 ppm was prepared by dissolving $0.2829 \mathrm{~g}$ of $\mathrm{K}_{2} \mathrm{Cr}_{2} \mathrm{O}_{7}$ in $100 \mathrm{~mL}$ volumetric flask with DDW. Intermediate standard solutions of $300 \mathrm{ppm}$ and 100 ppm were prepared through dilution from the stock solution.

A blank (all in the absence of analyte) and five working standard solutions of different chromium (VI) concentrations were prepared from the 100 ppm intermediate standard solution using serial dilution. A DPC reagent was prepared by first dissolving a $0.25 \mathrm{~g}$ of DPC in $5 \mathrm{~mL}$ acetone and then diluted to $100 \mathrm{~mL}$ with DDW. A $1 \mathrm{~mL}$ DPC solution was added to each working solutions including the blank for complexing chromium (VI) (Pranvera, 2009) and a pink color was observed except in the blank. The six working solutions were finally diluted to $50 \mathrm{~mL}$ with $\mathrm{pH} 2 \mathrm{PBS}$ and were analyzed for $\mathrm{Cr}(\mathrm{VI})$ using the UV-Visible spectrophotometer at a wave length of $540 \mathrm{~nm}$.

Table 1.The optimized operating conditions for ICP-OES

\begin{tabular}{ll}
\hline Parameter & Condition \\
\hline Power & $1100 \mathrm{~W}$ \\
Nebulizer flow rate & $0.65 \mathrm{~L} / \mathrm{min}$ \\
Nebulization pressure & $1.75 \mathrm{bar}$ \\
Pump speed & $20 \mathrm{rpm}$ \\
Plasma flow & $15 \mathrm{~L} / \mathrm{min}$ \\
Auxiliary flow & $0 \mathrm{~L} / \mathrm{min}$ \\
Sheath flow & $0.2 \mathrm{~L} / \mathrm{min}$ \\
Wavelength & 267.716 \\
\hline
\end{tabular}

Furthermore, working solutions of 0.0, 0.4, 2.0, $10.0,50.0,150.0$ and $250.0 \mathrm{ppm}$ were prepared from the $300 \mathrm{ppm}$ intermediate standard solution by serial dilution. Each working solution was diluted to $50 \mathrm{~mL}$ of final volume and analyzed for total chromium using the ICP-OES under optimized operating conditions (Praveen et al., 2010) summarized in Table 1.

\section{Preparation of real tannery sample solutions}

A $25 \mathrm{~mL}$ effluent sample, previously filtered on a filter paper was transferred to a $100 \mathrm{~mL}$ volumetric flask. In a similar manner as in the working solutions' preparation, $1 \mathrm{~mL}$ of DPC was added to each $100 \mathrm{~mL}$ volumetric flask and diluted with $\mathrm{pH}$ 2 PBS up to the mark. The final real tannery sample solution was analyzed for $\mathrm{Cr}(\mathrm{VI})$ using the UVVisible spectrophotometer at a wave length of 540 $\mathrm{nm}$.

In order to determine the total chromium content in the real tannery effluent samples using ICP-OES instrument, the effluent samples were digested using reported wet digestion procedure (APHA, 1998) with minor modification. Briefly: $50 \mathrm{~mL}$ of each sample was taken in to a $250 \mathrm{~mL}$ beaker and $10 \mathrm{~mL}$ of $\mathrm{HNO}_{3}$ and $\mathrm{HClO}_{4}$ mixture (1:1) was added to the sample, covered with watch glass and then digested for 1 hour at $120{ }^{\circ} \mathrm{C}$ until a clear solution was obtained. Each digested outcome was allowed to cool and was diluted to $100 \mathrm{~mL}$ with DDW. Unlike the others, the digestion outcome of Haik before treatment was diluted to $1000 \mathrm{~mL}$ with DDW for the original sample solution was intense green color indicating relatively high chromium concentration.

Recovery study and method detection limit 
The two commonly used quality assurance methods are the percent recovery $(\% \mathrm{R})$ and method detection limit (MDL) (Nancy, 2001). To determine the percent recovery of a spike, an effluent sample was split into two portions and a known amount of a standard solution of analyte was added (spiked) to one portion and the concentration for both the spiked (F) and the unspiked (I) were measured under similar experimental conditions. The percent recovery, \%R, was calculated following equation 1 .

$$
\% R=\frac{F-I}{A} * 100 \%-----------------1
$$

Where $A$ is the concentration of analyte added to the spiked portion.

The method detection limit (MDL) defined as the minimum concentration of a substance that can be measured and reported with $99 \%$ confidence that the analyte concentration is greater than zero (Electronic Code of Federal Regulations, 2015) was calculated employing equation 2 .

$$
\begin{aligned}
& D L=\frac{3 S}{b}-----------------------2 \\
& \mathrm{DL}=\frac{3 \mathrm{~S}}{\mathrm{~b}}
\end{aligned}
$$

Where $\mathbf{S}$ is the standard deviation of replicate analyses of the blank and $\mathbf{b}$ is a slope of regression equation (Electronic Code of Federal Regulations, 2015).

\section{Statistical analysis of data}

Tannery effluent samples were collected from Haik and Debre Berhan tanneries before and after treatment in three sampling times. The collected samples were acidified, digested, filtered, and analyzed during which a number of random errors may be introduced. One way ANOVA (Analysis of Variance) was used to examine whether the results between months were statistically different or not.

\section{RESULTS AND DISCUSSION}

Determination of chromium (VI) in the discharged tannery effluents using UV-Visible spectrophotometry

To determine the chromium (VI) concentration in the real tannery effluent samples collected from Haik and Debre Berhan tanneries, a UV-Vis spectrometric calibration curve was first obtained for $0.0,0.02,0.06,0.18,0.54$ and $1.62 \mathrm{ppm}$ of $\mathrm{Cr}$ (VI). Absorbance was found linearly dependent on the concentration of chromium (VI) in the studied concentration range with a linear regression equation, determination coefficient $\left(\mathrm{R}^{2}\right)$, and method detection limit of $\mathrm{A}=0.00148+0.51204 \mathrm{C}(\mathrm{ppm})$, 0.99842 , and $6.8 \times 10^{-3} \mathrm{ppm}$, respectively (Figure $3)$.

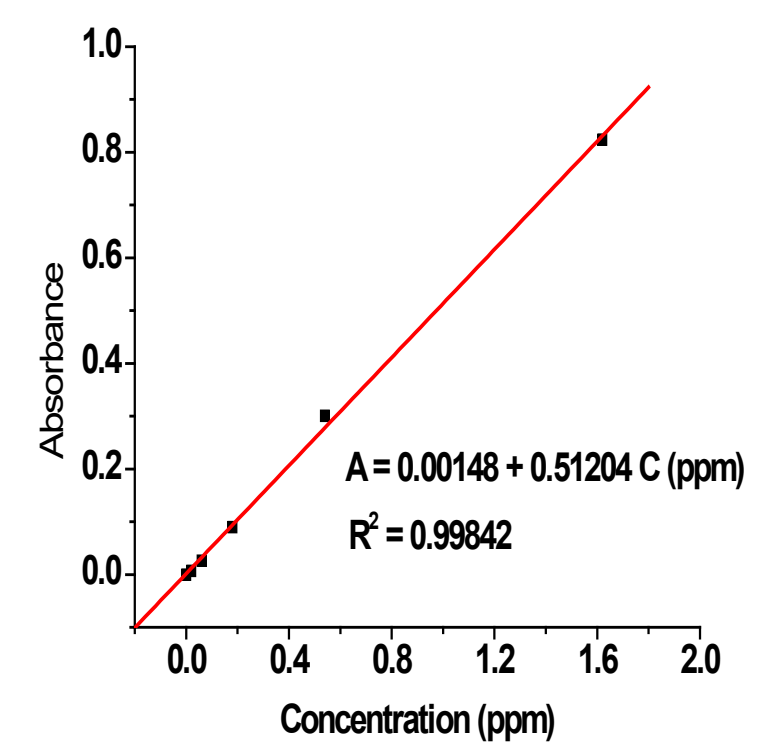

Figure 3. Plot of absorbance versus chromium (VI) concentration $(0.0,0.02,0.06,0.18,0.54$ and $1.62 \mathrm{ppm})$. 
Table 2. Summary of the level of chromium (VI) in samples collected from Haik and Debre Berhan tanneries before and after treatment in three sampling times (in ppm)

\begin{tabular}{lcccc}
\hline $\begin{array}{l}\text { Sampling } \\
\text { site }\end{array}$ & $\begin{array}{c}\text { Sampling month } \\
\text { Feb.12-13, 2015 } \\
\text { (Mean } \pm \text { SD) }\end{array}$ & $\begin{array}{c}\text { May 07-08, 2015 } \\
(\text { Mean } \pm \text { SD })\end{array}$ & $\begin{array}{c}\text { May 27-29, 2015 } \\
(\text { Mean } \pm \text { SD })\end{array}$ & $\begin{array}{c}\text { Average over } \\
\text { three sampling times } \\
\left(\text { Mean } \pm \text { SD }_{\mathrm{p}}\right)\end{array}$ \\
\hline Haik BT & $1.088 \pm 0.020$ & $0.426 \pm 0.130$ & $0.340 \pm 0.012$ & $0.618 \pm 0.076$ \\
Haik AT & $0.040 \pm 0.010$ & $0.309 \pm 0.110$ & $0.020 \pm 0.001$ & $0.123 \pm 0.064$ \\
$\begin{array}{l}\text { Debre } \\
\text { Berhan BT }\end{array}$ & $0.052 \pm 0.010$ & $0.114 \pm 0.006$ & $0.043 \pm 0.009$ & $0.070 \pm 0.009$ \\
$\begin{array}{l}\text { Debre } \\
\text { Berhan AT }\end{array}$ & $0.024 \pm 0.008$ & $0.090 \pm 0.004$ & $0.004 \pm 0.001$ & $0.039 \pm 0.005$ \\
\hline
\end{tabular}

$\mathrm{SD}_{\mathrm{p}}=$ Pooled standard deviation for $\mathrm{n}=9, \mathrm{BT}=$ Before Treatment, and AT $=$ After Treatment

Under the same conditions of analysis as for the working standard solutions, the absorbance of chromium (VI) in each of the tannery effluent samples was measured using UV-Visible spectrophotometry. The chromium (VI) concentrations in the tannery effluent samples collected from Haik and Debre Berhan tanneries in three sampling times are summarized in Table 2.

Basically, while chromium (VI) concentration results in samples collected before the treatment plant are indicators of whether the factory was in the tanning step or not, its level in a sample collected after treatment plant is a measure of the efficiency of the treatment plant and the favorability of the conditions in the treatment pond for the conversion of chromium (III) to chromium (VI). Thus, the Cr (VI) level most important in assessing the impact of the factory effluent on the environment is its amount in the effluent sample collected just after the treatment plant.
Although the allowed level of chromium (VI) in the discharged tannery effluent set by many countries is about $0.1 \mathrm{ppm}$ (Jakov, 2005), the limit set by WHO is in the range of 0.05 to 0.06 ppm (WHO, 1996). As can be seen from Table 2 , while the average $\mathrm{Cr}$ (VI) level in the effluents of the two factories sampled in February 12-13 and May 27-29, 2015 was under the National and WHO permissible level, a level much higher than the permissible level in the sample collected from the two factories in May 07-08, 2015 was a confirmation for the inefficient treatment plant the factories have and hence degree the factories are polluting the environment.

\section{Determination of total chromium in the discharged tannery effluents using ICP-OES}

The total chromium concentration in tannery effluent samples collected from Haik and Debre Berhan tanneries before and after treatment was determined using the ICP-OES. The ICP-OES signal 


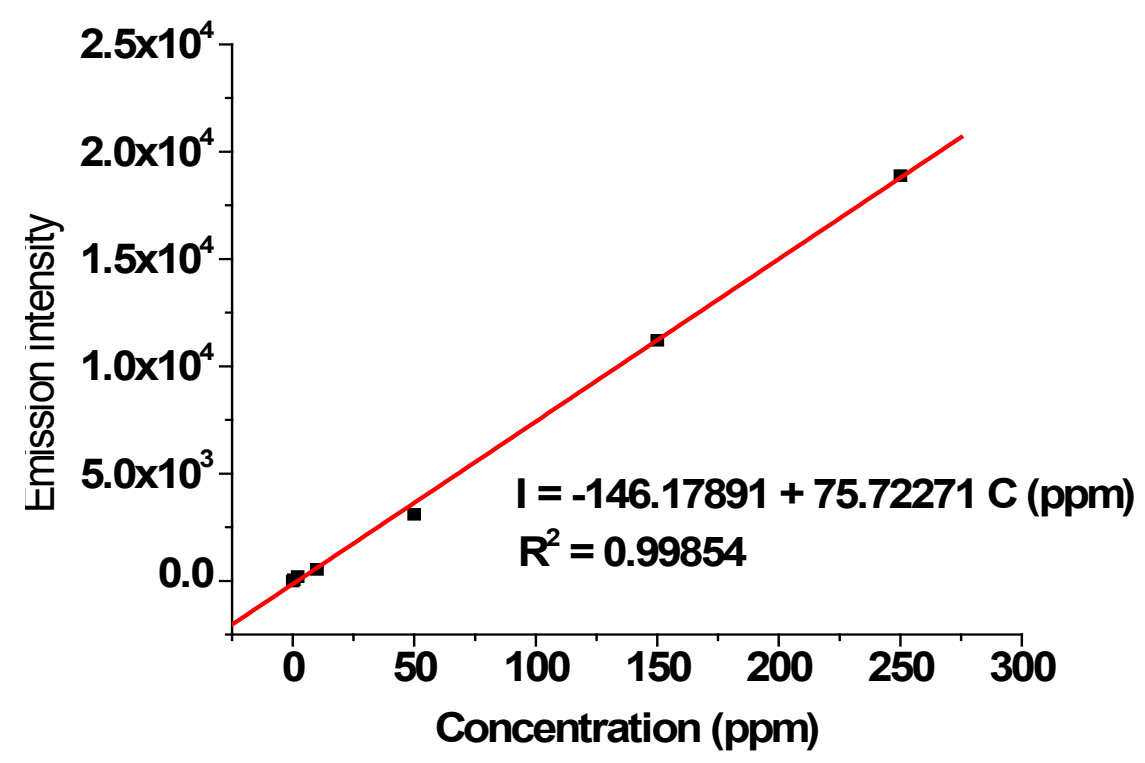

Figure 4. Plot of ICP-emission intensity versus total chromium concentration $(0.0,0.4,2.0,10.0,50.0$, 150.0 and $250.0 \mathrm{ppm})$.

intensity was found to be linearly dependent on the total chromium concentration (Figure 4) of standard solution in the range 0.0 to $250.0 \mathrm{ppm}$ with linear regression equation, correlation coefficient and detection limit of $\mathrm{I}=-146.18+75.72 \mathrm{C}(\mathrm{ppm})$, 0.99854 , and $3.3 \times 10^{-2} \mathrm{ppm}$, respectively.

Under the same conditions as for the working standard solutions, the emission intensity and hence concentration of total chromium in the real tannery effluent samples collected from Haik and Debre Berhan tanneries both before and after treatment calculated using the calibration curve regression equation are summarized in Table 3.

As can be seen from the table, the total chromium concentrations in effluent samples collected from the discharged effluents of Haik and Debre Berhan

Table 3. Summary of the level of total chromium in samples collected from Haik and Debre Berhan tanneries before and after treatment in three sampling times (in ppm)

\begin{tabular}{lcccc}
\hline \multirow{2}{*}{$\begin{array}{l}\text { Sampling } \\
\text { site }\end{array}$} & $\begin{array}{c}\text { February12-13, } \\
2015 \\
(\text { Mean } \pm \text { SD) }\end{array}$ & $\begin{array}{c}\text { May 07-08, 2015 } \\
(\text { Mean } \pm \text { SD })\end{array}$ & $\begin{array}{c}\text { May 27-29, } \\
2015 \\
(\text { Mean } \pm \text { SD })\end{array}$ & $\begin{array}{c}\frac{\text { Average over }}{\text { three sampling }} \\
\text { times }\end{array}$ \\
\hline Haik BT & $2,046.5 \pm 1.5$ & $815.5 \pm 3.8$ & $11,454.8 \pm 0.7$ & $4,772.3 \pm 2.4$ \\
Haik AT & $6.1 \pm 0.1$ & $44.6 \pm 1.8$ & $1,127.4 \pm 2.4$ & $392.7 \pm 1.7$ \\
$\begin{array}{l}\text { Debre } \\
\text { Berhan BT }\end{array}$ & $284.2 \pm 1.0$ & $59.1 \pm 1.0$ & $1,195.1 \pm 1.2$ & $512.8 \pm 1.1$ \\
$\begin{array}{l}\text { Debre } \\
\text { Berhan AT }\end{array}$ & $49.0 \pm 0.4$ & $12.5 \pm 0.1$ & $913.6 \pm 0.3$ & $325.0 \pm 0.3$ \\
\hline \multicolumn{4}{c}{$\mathrm{SD}_{\mathrm{p}}=$ Pooled standard deviation for $\mathrm{n}=9, \mathrm{BT}=$ Before Treatment, and AT $=$ After Treatment }
\end{tabular}


tanneries just after the respective treatment plants were above the permissible limit set by Ethiopia (2 ppm) (EEPA, 2005). In spite of the fact that the total chromium concentration is reduced in amount after the treatment, still considerable amount of total chromium concentration has been discharged to the environment. This indicated that the treatment plants the factories are using were inefficient to reduce the chromium concentration to an acceptable level. Among the three sampling times, highest amount of total chromium was recorded in the samples collected in May 27-29, 2015 which might be because the factories were in a chrome tanning step.

\section{Determination of chromium (III) in the discharged tannery effluents using the difference method}

In this study, a "difference method" approach was used to estimate the average concentration of chromium (III) present in the discharged effluent samples of Haik and Debre Berhan tanneries. Briefly; with the assumption that total chromium is the sum of the hexavalent and trivalent forms, the chromium (III) concentration in each sample was calculated by subtracting the chromium (VI) concentration from the total chromium concentration in the sample. Level of chromium (III) in the tannery effluent samples collected from Haik and Debre Berhan tanneries before and after treatment during the three sampling times is presented in Table 4.

As shown in the table, the trivalent chromium concentration was about the same as the total chromium indicating that the fraction of chromium converted to $\mathrm{Cr}$ (VI) was very small. The detection of considerable amount of trivalent chromium in the discharged effluents of both studied factories during the three sampling times is in agreement with the report value by Abass et al. (2005).

\section{Comparison of analytical results}

For each studied tannery factory, one way analysis of variance (ANOVA) statistical analysis at a confidence level of $95 \%$ was used to evaluate whether the average levels of chromium species in the discharged effluents sampled in different sampling times are significantly different or not.

Table 4. Summary of the level of chromium (III) in samples collected from Haik and Debre Berhan tanneries before and after treatment in three sampling times by a difference method (in ppm)

\begin{tabular}{lccc}
\hline Sampling site & \multicolumn{3}{c}{ Sampling month } \\
\cline { 2 - 4 } & Feb. 12-13, 2015* & May 07-08, 2015* & May 27-29, 2015* \\
\hline Haik BT & $2,045.4 \pm 1.5$ & $815.1 \pm 3.7$ & $11,454.5 \pm 0.7$ \\
Haik AT & $6.1 \pm 0.1$ & $44.3 \pm 1.7$ & $1,127.4 \pm 2.4$ \\
D/Berhan BT & $284.2 \pm 1.0$ & $59.0 \pm 1.0$ & $1,195.1 \pm 1.2$ \\
D/Berhan AT & $49.0 \pm 0.4$ & $12.4 \pm 0.1$ & $913.6 \pm 0.3$ \\
${ }^{*}$ Mean $\pm \mathrm{SD}_{\mathrm{p}} ; \mathrm{SD}_{\mathrm{p}=\text { pooled standard deviation }}$ & & \\
\end{tabular}


One way ANOVA analysis for total chromium in samples collected before and after treatment revealed significant difference $(p=0.00)$ among the three sampling seasons from each tannery. The Tukey pair wise analysis also confirmed that all possible pairs of average results are significantly different from each other.

One way ANOVA analysis for $\mathrm{Cr}(\mathrm{VI})$ amounts

Table 5. Summary of recovery results of hexavalent chromium using UV-VIS spectrometer

\begin{tabular}{|c|c|c|c|c|}
\hline Sampling site & *Initial (ppm) & Added (ppm) & Found (ppm) & $\% \mathrm{R}$ \\
\hline Haik BT & 0.1065 & 0.0300 & 0.1375 & $103.3 \%$ \\
\hline Haik AT & 0.0772 & 0.0200 & 0.0976 & $102.0 \%$ \\
\hline Debre Berhan BT & 0.0284 & 0.0120 & 0.0403 & $99.2 \%$ \\
\hline Debre Berhan AT & 0.0225 & 0.0100 & 0.0323 & $98.0 \%$ \\
\hline
\end{tabular}

Table 6. Summary of recovery results of total chromium using ICP-OES

\begin{tabular}{lcccc}
\hline Sampling site & *Initial $(\mathrm{ppm})$ & Added $(\mathrm{ppm})$ & Found $(\mathrm{ppm})$ & $\%$ R \\
\hline Haik BT & 17.9 & 5.0 & 23.00 & $101.4 \%$ \\
Haik AT & 8.9 & 3.0 & 11.80 & $97.0 \%$ \\
Debre Berhan BT & 10.6 & 4.0 & 14.50 & $97.3 \%$ \\
Debre Berhan AT & 2.5 & 0.8 & 3.3 & $96.3 \%$ \\
\hline
\end{tabular}

\footnotetext{
* Concentration of total chromium in real effluent of the tanneries after dilution; BT= Before Treatment; AT = After
} Treatment; and $\% \mathrm{R}=$ Percent recovery 


\section{Method verification}

The ability to provide timely, accurate and reliable data is central to the role of analytical methods. Method verification is the process of providing the acceptance of the developed analytical method for its intended purpose. Since there was no certified reference material (tannery effluent) in our laboratory, the validity of the procedures for UV-VIS and ICP-OES analysis were checked by recovery studies. The percentage recovery for chromium (VI) and total chromium in the two tannery effluent samples before and after treatment are presented in Tables 5 and 6.

As shown in the tables, the percentage recovery for $\mathrm{Cr}(\mathrm{VI})$ and total chromium in the effluent samples were between 98.0 to $103.3 \%$ and 96.3 to $101.4 \%$, respectively indicating an excellent recovery of spiked standards from the effluent samples. Hence, the applicability of the reported methods used for the determination of hexavalent chromium and total chromium in tannery effluent samples was verified.

\section{Comparison of the results with permitted levels of chromium species}

The maximum permitted level of chromium species in a tannery effluent discharged to a water body has been reported by different countries and WHO. Thus, comparison of the level of chromium species detected in the discharged tannery effluents of the studied factories with the permitted levels by different countries (guidelines) may help concerned stakeholders to evaluate the extent our tannery fac-

Table 7. Results of the present study against permitted levels of chromium species (ppm) in different guidelines

\begin{tabular}{|c|c|c|c|c|}
\hline Country/Institution & $\mathrm{Cr}_{\mathrm{T}}(\mathrm{ppm})$ & $\begin{array}{l}\mathrm{Cr}(\mathrm{III}) \\
(\mathrm{ppm})\end{array}$ & Cr(VI) (ppm) & References \\
\hline Ethiopia & 2 & - & 0.1 & (EEPA, 2005) \\
\hline Italy & 2 & - & 0.2 & (Jakov, 2005) \\
\hline India & 2 & - & 0.1 & (Jakov, 2005) \\
\hline France & 1.5 & - & 0.1 & (Jakov, 2005) \\
\hline Tunisia & & 0.5 & 0.01 & (Jakov, 2005) \\
\hline Brazil & - & 1 & 0.1 & $\begin{array}{l}\text { (Quevauviller and } \\
\text { Marrier, 1995) }\end{array}$ \\
\hline USPS & - & 0.5 & 0.1 & (Hossain et al., 2005) \\
\hline Europe general & 2 & - & 0.2 & (WHO,1996) \\
\hline WHO limit & - & - & $0.05-0.06$ & (WHO,1996) \\
\hline Haik tannery & $392.7 \pm 1.7$ & $392.6 \pm 1.7$ & $0.123 \pm 0.064$ & This study \\
\hline $\begin{array}{l}\text { Debre Berhan } \\
\text { tannery }\end{array}$ & $391.7 \pm 0.8$ & $391.7 \pm 0.8$ & $0.039 \pm 0.005$ & This study \\
\hline
\end{tabular}


tories are pollution the environment. The level of chromium species in the discharged effluent of the studied tanneries versus the permitted levels by different countries is summarized in Table 7.

Surprisingly, the average total chromium concentration in the discharged effluents of Debre Berhan and Haik tanneries were over 100 folds of magnitude of the National permitted limit. Although the average hexavalent chromium level in the discharged effluent of Debre Berhan tannery is slightly below the limit of the Ethiopian guideline, that of Haik tannery is still above the permitted level confirming the severity of pollution.

\section{CONCLUSIONS}

The level of chromium species (total, hexavalent, and trivalent chromium) in the discharged effluents collected from Haik and Debre Berhan tanneries over three sampling times (February 12-13, May 07-08, and May 27-29, 2015) was assessed using UV-Visible spectrophotometry and ICP-OES. The average hexavalent chromium concentration in the discharged effluent of Haik after treatment ranged between 0.020 to $0.309 \mathrm{ppm}$ while in the effluent from Debre Berhan tannery between 0.004 to $0.094 \mathrm{ppm}$. This indicated that Haik tannery disposes its effluent with $\mathrm{Cr}(\mathrm{VI})$ dose of even higher than the National permitted level. Debre Berhan tannery on the contrary disposes its effluent with a relatively lower $\mathrm{Cr}(\mathrm{VI})$ level although is observed to have a level above the WHO guidelines. Moreover, the total chromium levels in the effluents of the two factories after treatment ranged between 6.1 - 1,127.4 (Haik) and 12.5 - 913.6 (Debre Berhan), indicating that the factories are potentially polluting their environment. Recovery results in the range $96.3-103.3 \%$ of spiked standard chromium species in the real tannery effluent samples verified the applicability of the analytical methods for the determination of the chromium species in a complex matrix system. High level of total chromium in general and hexavalent chromium in particular in the discharged effluent after the treatment plant from both studied factories is an indication of the inefficient treatment plants the factories are using. Since the level of total chromium in the discharged tannery effluent of both studied factories is in a 100 folds higher than the permitted level, the efficiency perhaps functionality of the treatment plant they are claiming must therefore be checked. Moreover, concerned governmental offices should not only work towards expansion of such industries overlooking their potential effects on the environment.

\section{ACKNOWLEDGMENTS}

The authors greatly acknowledge the Chemistry Department of Bahir Dar University for providing us the necessary chemicals and working space. School of Chemical and Food Engineering of Bahir Dar University is also acknowledged for accessing the ICP-OES and UV-Vis instruments. The authors would also like to acknowledge the Amhara Land Administration and Environmental Protection Bureau and College of Science Research and Community Service for their financial support. Finally, our appreciation goes to the Haik and Debre Berhan Tanneries for permitting us to collect effluent samples.

\section{REFERENCES}

Abass, E., Alireza, M and Reza, V. (2005). Chromium (III) removal and recovery from tannery wastewater by precipitation process. 
American Journal of Applied Sciences 2(10): 1471-1473.

Abdel-Shafy, H.I., Hegemann, W and Genschow, E. (1995). Fate of heavy metals in the leather tanning industrial wastewater using anaerobic process. Journal of Environmental Management and Health 6(2): 28-33.

Abraha Gebrekidan and Afework Mulugeta(2009).

Environmental impacts of Sheba Tannery (Ethiopia) effluents on the surrounding water bodies. Bulletin of Chemical Society Ethiopia 23(2): 269-274.

Addis Mekonnen (2006). Determination of chromium (III) and chromium (VI) in the tannery effluents of Awash and Addis Ababa Leather Industries. M.Sc. Thesis, Addis Ababa University, Ethiopia.

Akcay, H., Oguz, A and Karapire, C. (2003). Study of heavy metal pollution and speciation in Buyak Menderes and Gediz river sediments. Water Research 37: 813-822.

APHA (American Public Health Association) (1998). Standard methods for the examination of water and wastewater, $20^{\text {th }}$ ed., APHA, Washington, DC, USA.

Arian, M.B and Kazi, T.G. (2008). Evaluation of physico-chemical parameters of Manchar Lake water and their comparison with other global published values. Pakistan Journal of Analytical and Environmental Chemistry 9(2): 101-109.

Balogh, I.S., Maga, I.M., Hargitai-Toth, A and Andruch, V. (2000). Spectrophotometric study of the complexation and extraction of chromium (VI) with cyanine dyes. Talanta 53(3): 543-549.

Benzer, S., Arslan, N and Y1lmaz, M. (2013).
Concentrations of metals in water, sediment and tissues of Cyprinus carpio from Mogan Lake (Turkey). Iranian Journal of Fisheries Sciences 12(1): 45-55.

Callahan, M.A., Slimak, M.W., Bagel, N and Grevatt, P.C. (1979). Water-Related Environmental Fate of 129 Priority Pollutants, Vol. II. U.S. EPA, Office of Water Planning and Standards, Office of Water and Waste Management, Washington, DC.

Dayananda, B. P and Revanasiddappa, H.D. (2007). Spectrophotometric determination of chromium by oxidation of prochlorperazine dimaleate. Oxidation Communications 30(1): 197-205.

Dhungana, T.P and Yadav, P.N. (2009). Determination of chromium in tannery effluent and study of adsorption of $\mathrm{Cr}(\mathrm{VI})$ on sawdust and charcoal from sugarcane bagasses. Journal of Nepal Chemical Society 23: 93-101.

Dixit, S and Tiwari, S. (2008). Impact assessment of heavy metal pollution of Shahpura Lake, Bhopal, India. International Journal of Environmental Research 2(1): 37-42.

Electronic Code of Federal Regulations. (2015). Protection of Environment: Definition and procedure for the determination of the method detection Limit—rev. 1.11, part 136.

EPA (1984). Health assessment document for chromium. Environmental Criteria and Assessment Office, Research Triangle Park, NC. EPA/600/8-83-014F. NTIS PB 85115905. Available from National Technical Information Service, Springfield, VA.

Fabiyi, F.A.S and Donnio, A.Z. (2007). Use of variamine blue as a chromogenic reagent 
for rapid spectrophotometric determination of nano amount of chromium. Synthesis and Reactivity in Inorganic, Metal-Organic, and Nano-Metal Chemistry 37(10): 809-812.

Girard, L and Hupert, J. (1996). Speciation of chromium (VI) and total chromium determination in welding dust samples by flow-injection analysis coupled to atomic absorption spectrometry. Talanta 43: 19651974.

Hagendorfer, H and Goessler, W. (2008). Separation of chromium (III) and chromium (VI) by ion chromatography and an inductively coupled plasma mass spectrometer as element selective detector. Talanta 76: 656-661.

Han, Z., Qi, L., Shen, G., Liu, W and Chen, Y. (2007). Determination of chromium (VI) by surface plasmon field enhanced resonance light scattering. Analytical Chemistry 79: 5862-5868.

Hossain, M.A., Kumita, M., Michigami, Y., Islam, T.S and Mori, S. (2005). Rapid speciation analysis of $\mathrm{Cr}(\mathrm{VI})$ and $\mathrm{Cr}$ (III) by reversed-phase high-performance liquid chromatography with UV detection. Journal of Chromatographic Science 43(2): 98-103.

Jakov, B. (2005). 15th session of the UNIDO leather and leather products industry panel, Leon, Mexico.

Juneva, S and Prakash, S. (2008). Electrophoretic study of chromium speciation in xylem sap of maize (Winter Crop). Chemical Speciation and Bioavailability 20(2): 55-63.

Kotai, J and Stasicka, Z. (2000). Chromium occurrence in the environment and methods of its speciation. Environmental Pollution 107(3): 263-283.
Kumar, S.J., Ostapczuk, P and Emons, H. (1997). Determination of total chromium in terrestrial and marine samples by electrothermal atomic absorption spectrometry after pressure digestion. Fresenius Journal of Analytical Chemistry 359: 171-175.

Li, W., Tai,CandGu,X.(2001). Spectrophotometric determination of chromium(VI) with $\mathrm{Cr}(\mathrm{VI})$ o-Cl-PF-TDPC ternary complex after preconcentration on an organic solventsoluble membrane filter. International Journal of Environmental and Analytical Chemistry 81:127-135.

Lin, T.W and Huang, S.D. (2001). Direct and simultaneous determination of copper, chromium, aluminum, and manganese in urine with a multielement graphite furnace atomic absorption spectrometry. Analytical Chemistry 73: 4319-4325.

Miller, N.J and Mille, C.J. (2000). Statistical Chemometrics for Analytical Chemistry, 4th ed., Pearson Practice Hall: England.

Monteiro, M.I.C., Fraga, I.C.S., Yallouz, A.V., Oliveira, N.M.M and Ribeiro, S.H. (2002). Determination of total chromium traces in tannery effluents by electrochemical atomic absorption spectrometry, flame atomic absorption spectrometry and UV-visible spectrophotometric methods. Talanta 58: 629-633.

Moore, F., Orghani, G and Qishla, A. (2009). Assessment of heavy metal contamination in water and surface sediments of the Maharlu saline Lake, Swiran. Iranian Journal of Science and Technology, Transaction A 33(1): 44-54.

Nancy, W.W. (2001). Quality staff strategic plan. U.S. Environmental Protection Agency. 
Pankow, J.F and Janauer, G.E. (1974). Analysis for chromium traces in natural waters: preconcentration of chromate from $\mathrm{ppb}$ levels in aqueous solutions by ion exchange. Analytica Chimica Acta 69: 97-104.

Pranvera L. (2009). Determination of Cr (VI) in environmental samples evaluating $\mathrm{Cr}$ (VI) impact in a contaminated area. Journal of International Environmental and Application Science 4(2): 207-213.

Praveen, S., Perkin, E and Shelton, C.T. (2010). Analysis of wastewater for metals using ICPOES. www.perkinelmer.com, USA.

Quevauviller, P.H and Marrier, E. (1995). Quality Assurance for Environmental Analysis In: Quality Assurance for Environmental Analysis. Techniques and Instrumentation in Analytical Chemistry 17: 1-25.

Revanasiddappa, H.D and Kiran Kumar, T.N. (2002). Rapid spectrophotometric determination of chromium with trifluoperazine hydrochloride. Chemical Analysis 47: 311-313.

Revanasiddappa, H.D and Kiran, Kumar, T.N. (2003). Highly sensitive spectrophotometric determination of chromium using leuco xylene cyanol FF. Talanta 60: 1-8.

Ricardo, S., Manuel, C.C., Maria Ines, C.M., Sergio d e Souza, H.J., Fernanda, V.M.P., Lilian, I.D.S., Arnaldo, A.N and Ricardo, E.S. (2009). Simultaneous speciation of chromium by spectrophotometry and multicomponent analysis. Chemical Speciation and Bioavailability 21(3): 153-160.

Satyajit, R and Sukalyan, D. (2012). Assessment of water quality around mine sites. Thesis, Department of mining engineering, National institute of Technology, Rourkela, India.

Siraj, S., Islam, M.M., Das, P.C., Masum, S.M, Jahan, I.A and Shajahan, M. (2012). Removal of chromium from tannery effluent using chitosan-charcoal composite. Journal of Bangladesh Chemical Society 25(1): 53-61.

Telepcakova, M., Andruch, V and Balogh, I.S. (2005). Indirect extractionspectrophotometric determination of chromium. Chemical Papers 59(2): 109-112.

The EFDRE Environmental Protection Authority (2005). Environmental impact Assessment Guideline for Tanneries. Addis Ababa Ethiopia.

United Nations Conference on Trade and Development. (2002). Investment and innovation policy review Ethiopia. United Nations conference on trade and development investment. UNCTAD/ITE/IPC/Misc.4.

Zaitoun, M.A. (2005). Spectrophotometric determination of chromium (VI) using cyclam as a reagent. International Journal of Environmental and Analytical Chemistry 85: 399-407.

Zenabu Yirgu (2011). Accumulation of certain heavy metals in Nile Tilapia (oreochromis niloticus) fish species relative to heavy metal concentrations in the water of Lake Hawassa. M.Sc. Thesis, Addis Ababa University, Ethiopia. 